\title{
INCOMPLETE FAMILY DATA, SELECTION AND POPULATION STUDIES OF TRANSFERRINS AND BLOOD GROUPS IN CATTLE.
}

\author{
D. W. COOPER* and J. RENDEL \\ Department of Animal Breeding, Agricultural College of Sweden, Uppsala 7, Sweden
}

Received 22.iii.67

\section{InTRODUGTION}

APART from man, the blood groups of cattle are better known than those of any other organism. At least 12 different systems of red cell antigens are known and in the last decade 13 enzyme and other protein polymorphisms have been detected in blood and milk (see Cohen, 1962; Kiddy, 1964; Matousek, 1965; Grosclaude, 1967). The principal impetus for this effort has been utilitarian, the use of blood groups to resolve cases of doubtful parentage. The known variability of cattle red cell antigens is very great, greater than that of man; to encounter two animals with the same blood type is very unlikely and so many breed societies and artificial insemination organisations make blood typing a requirement of registration, particularly for the top strata of breeding bulls. The hope that something of importance might be discovered about the productive capacity of the animal has acted as an extra incentive (reviewed by Maijala, 1966). In the United States, laboratories for blood typing service and research have been in operation since about 1950 and in Scandinavia since 1954. Elsewhere the expansion has been very great in recent years.

In the course of their operation over a period of years, cattle blood group laboratories compile considerable genetic data. Such data have frequently been used to study the population genetics of cattle, which is becoming increasingly well described. But hitherto comparatively little effort has been made to use these segregation data to study the selective forces affecting the polymorphisms. One reason for this neglect is that much of the reliable family data obtained by blood group laboratories is not complete. The sire and offspring, or the dam and offspring, may be typed, but less commonly all three.

Geneticists are accustomed to dealing with complete family data (C.F.D.) and with population data (P.D.), but they have seldom used incomplete family data (I.F.D.). Consequently, cattle blood group workers, taking their genetical techniques from other fields, have tended to think in terms of C.F.D. and P.D. and overlook the use which can be made of I.F.D. This has meant that most workers have used P.D. only because C.F.D. are often not readily accessible.

Unfortunately P.D. are sensitive to heterogeneity of gene frequency between subpopulations as well as to departures from Mendelian segregation ratios. It has never been clear how much this matters in cattle. The small effective population size of some breeds or strains within breeds suggests that

* C.S.I.R.O. Overseas postgraduate student. 
such heterogeneity may be sufficient to render the Hardy-Weinberg expectations invalid (Robertson, 1965) and so investigation of the question is necessary. In this paper, we will show that I.F.D. allow detection of heterogeneity of gene frequency and the effect of selection in such a way that the two can be distinguished.

Data from the FV and $\mathrm{Z}$ blood group systems and the transferrin system will be examined. We hope to provide an example which other blood group laboratories will follow by analysing their data. In order to assess our own results we have reviewed previously published family and population data. There exists a fairly large amount of data for the transferrin system. Our examination of these data has allowed us to make a critical re-appraisal of Ashton's (1965) argument that this polymorphism may be a balanced one.

\section{Material}

The study will be based on (1) information in numerous publications and (2) on data accumulated in our laboratory during the last decade. Our own data comprised 2897 registered bulls of the Swedish Red and White breed (SRB), which had been tested against 38-45 blood typing reagents detecting red cell antigens in 9 genetic systems. The sample included all SRB bulls used in artificial insemination or sold at the official breed sales during the period 1955-65. In addition it included stud bulls in a number of bull-breeding herds. The sample is representative of the top strata of the breed. The age at testing varied considerably. When the test for red cell antigens was first introduced in 1955, all available A.I. bulls were tested and so the sample includes 138 bulls born as early as in the period 1940-49. The bulls born after 1953 were usually tested when 12-24 months old, though in recent years there has been a tendency towards a decrease in age as the A.I. centres tend to buy their bulls as calves. The vast majority of the bulls have for some period of time been used for artificial or natural service.

As in most populations of breeding bulls this sample included animals of various degrees of relationship. The bulls were the progeny of a total of 707 sires, of which 330 were included in the red cell antigen tested sample. These 330 sires had a total of 1953 offspring in the sample. Their number of offspring varied from 1 to 67 with an average of $5 \cdot 9$ and a median of 13 .

In 1959 transferrin testing was initiated. Transferrin type was available on 1685 animals, and of these 597 had also a transferrin tested sire. The larger part of the transferrin testing was carried out by Dr B. Gahne in our laboratory. The tests for red cell antigens were carried out as described by Rendel (1958) and the transferrin typing as given by Gahne (1961).

\section{Heterogeneity of GeNe fReQuency in GATtle populations: METHODS FOR ITS DETEGTION}

Heterogeneity of gene frequency arises because of the limited number of male parents in any one generation and the consequent rather large random changes in gene frequency which can occur from generation to generation. Most breeds tend to be broken up into subpopulations between which there is restricted genetic exchange and so rather rapid genetic drift occurs. Examples of this phenomenon have been given for blood group data for Swedish (Rendel, 1958, 1963), Danish (Neimann-Sørensen, 1958), and Dutch cattle (Bouw, 1960), for transferrins in British cattle (Jamieson, 1966) 
and milk proteins in Swedish cattle (Sandberg, 1967). There may be two effects upon the Hardy-Weinberg expectations depending upon the mating practices within the breed:

1. The Wahlund effect. Wahlund (1928) first showed that if a population is subdivided into different subpopulations with differing gene frequencies, the expectations for the proportions of genotypes in the whole population are no longer given by the Hardy-Weinberg expectations. Instead, for the two-allele case, the two homozygous classes are each increased by a proportion equal to the variance in gene frequency between subpopulations and the heterozygous class is decreased by a proportion equal to twice that amount. Jamieson (1966) has found this effect in British Friesians.

2. The Robertson effect. Robertson (1965) has called attention to another possibility. In a single herd, the limited number of bulls make it likely that large random differences in gene frequency between bulls and cows can occur. Robertson shows that the number of heterozygotes will be increased over Hardy-Weinberg expectations by a proportion equal to $1 / 8 M$, where $M$ is the number of sires. Thus, if an attempt is made to circumvent Wahlund's effect by analysing data within herds, Robertson's effect may be enconntered. Robertson himself only considered the possibility of sex differences within herds. The same effect could be obtained when the bulls used in a breed come from one particular section of the breed, whose gene frequency differs from that of most other parts of the breed.

The existence of these two effects places the cattle geneticist in a predicament. Usually there will not be enough ancillary information to judge the importance of the two effects. The P.D. themselves do not have enough degrees of freedom to test for the effects of population structure and selection separately. However, if I.F.D. are available one can detect Wahlund's effect and circumvent Robertson's effect. Essentially, this method is an expansion of a suggestion by Cooper (1966).

Consider a population (e.g. a breed of cattle) subdivided into a series of subpopulations (e.g. herds). There are two non-dominant alleles $A_{1}$ and $A_{2}$ and the frequency of $A_{1}$ in the $i$ th population is $p_{i}$. The overall frequency in the whole population, i.e. the mean of the $p_{i} \mathrm{~s}$ is $p$. Suppose that I.F.D. for the whole population is available. It is a relatively easy matter to show that the proportions of the various parental genotypes and parental-offspring combinations are as in table 1 .

Here $V$ is the variance in gene frequency between any subpopulations and $X$ is the third moment of $p_{i}$ about $p$. Note that both $V$ and $X$ are characteristics of the population and not of any sample from it; $V$ is not the sampling variance but it is a measure of the degree of heterogeneity of the gene frequency. The observed numbers are indicated by $O$ and an appropriate subscript, for example $O_{12 \cdot 11}$ designates the observed number $A_{1} A_{1}$ progeny from $A_{1} A_{2}$ parents.

Assuming that $V=X=0$, it is possible to obtain four observed ratios from table 1 for which there are simple expectations. These are:

and

$$
\left.\begin{array}{l}
A_{1} A_{1}: A_{1} A_{2} \text { progeny from } A_{1} A_{1} \text { parents } \\
A_{1} A_{1}: A_{2} A_{2} \text { progeny from } A_{1} A_{2} \text { parents } \\
A_{1} A_{2}: A_{2} A_{2} \text { progeny from } A_{2} A_{2} \text { parents }
\end{array}\right\}=p:(1-p)
$$

$$
\left(A_{1} A_{1}+A_{2} A_{2}\right): A_{1} A_{2} \text { progeny from } A_{1} A_{2} \text { parents }=1: 1 \text {. }
$$


The first three ratios will be called the gametic gene ratios. These expectations are shown in table 2 together with the possible causes of significant departure from them.

\section{TABLE 1}

Expected proportions and observed numbers amongst incomplete family data (I.F.D.) taken from a genetically subdivided population

Available parent

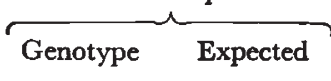

Progeny. Expected proportions and observed numbers of genotype

$$
\begin{array}{ccccc}
A_{1} A_{1} & p^{2}+V & p^{3}+3 p V+X & p^{2}(1-p)+(1-3 p) V-X & - \\
& & O_{11.11} & O_{11.12} \\
A_{1} A_{2} & 2 p(1-p)-2 V & p^{2}(1-p)+(1-3 p) V-X & p(1-p)-V & p(1-p)^{2}+(2-3 p) V+X \\
& & O_{12.11} & O_{12.12} & O_{12.22} \\
A_{2} A_{2} & (1-p)^{2}+V & - & p(1-p)^{2}-(2-3 p) V+X & (1-p)^{3}+3(1-p) V-X \\
& & - & O_{22.12} & O_{22.22}
\end{array}
$$

$V=$ Variance in gene frequency between subpopulations.

$X=$ Third moment of the distribution of the subpopulation gene frequencies about their mean, $p$.

$p=$ Gene frequency for the entire population.

\begin{tabular}{|c|c|c|c|c|c|}
\hline \multirow[b]{2}{*}{$\begin{array}{l}\text { Description } \\
\text { of the test }\end{array}$} & \multirow[b]{2}{*}{ Observed } & \multirow[b]{2}{*}{ Expected } & \multicolumn{3}{|c|}{$\begin{array}{c}\text { Expectations affected }(+) \text { and } \\
\text { unaffected }(-) \text { by }\end{array}$} \\
\hline & & & Viability & $\begin{array}{l}\text { Wahlund's } \\
\text { effect }\end{array}$ & $\begin{array}{l}\text { Robertson's } \\
\text { effect }\end{array}$ \\
\hline Viability ratio & $\left(O_{12.11}+O_{12.22}\right): O_{12.22}$ & $1: 1$ & + & - & - \\
\hline $\begin{array}{l}\text { Heterogeneity of } \\
\text { gametic gene } \\
\text { ratios }\end{array}$ & $\begin{array}{l}O_{11.11}: O_{11.12} \\
O_{12.11}: O_{12.22} \\
O_{22.12}: O_{22.22}\end{array}$ & $p:(1-p)^{*}$ & + & + & - \\
\hline $\begin{array}{l}\text { Hardy-Weinberg } \\
\text { equilibrium in } \\
\text { parent }\end{array}$ & $\begin{array}{l}\text { Parental genotypic } \\
\text { ratios }\end{array}$ & $p^{2}: 2 p(1-p):(1-p)^{2}$ & + & + & + \\
\hline
\end{tabular}

TABLE 2

Expectations and possible causes of significant departures for $\chi^{2}$ test on incomplete family data (I.F.D.)

* Assumes $V=X=0$, table 1 .

From table 2 it can be seen that the above tests will show if there are:

(1) differences in viability between genotypes;

(2) heterogeneity of gene frequency in the population (Wahlund's effect);

(3) sex differences in gene frequency (Robertson's effect).

In general, the action of the three causes can be separately detected by the pattern of results obtained by testing with $\chi^{2}$ and the direction of any significant departures from expectation. 
For a locus with more than two alleles, separate analyses can be made such that the presence versus absence of each allele is considered.

Also, if $A_{j}$ represents any other alleles besides $A_{1}$ and $A_{2}$, the frequencies of $A_{1} A_{1}: A_{1} A_{2}: A_{2} A_{2}: A_{1} A_{j}: A_{2} A_{j}$ amongst the progeny of $A_{1} A_{2}$ parents are $\frac{1}{2} p_{1}: \frac{1}{2}\left(p_{1}+p_{2}\right): \frac{1}{2} p_{2}: \frac{1}{2} p_{j}: \frac{1}{2} p_{j}$ respectively. Hence $\left(A_{1} A_{1}+A_{2} A_{2}\right): A_{1} A_{2}$ and $A_{1} A_{j}: A_{2} A_{j}$ are both equal to $1: 1$.

In addition to carrying out these tests based upon I.F.D., heterogeneity of the gene frequencies between years was also tested in our data, and so was the Hardy-Weinberg equilibrium within years.

\section{Results}

\section{Analyses of published segregation and population data}

The FV and Z systems. Stormont (1952) and Neimann-Sørensen (1958) presented segregation data for 341 and 225 matings respectively in the FV system and 722 and 357 matings respectively in the $\mathrm{Z}$ system, where at least one of the parents was of the heterozygous type $(\mathrm{F} / \mathrm{V}$ or $\mathrm{Z} /-)$. The distribution of the offspring was very close to expectation. The ratio between homozygotes and heterozygotes was 280:286 for the FV and 532:547 for the $\mathrm{Z}$ system. No details of sex of parent were given for the matings. The effects, if any, of heterozygous superiority and maternal-foetal antigenic incompatability tending to eliminate heterozygotes could not therefore be separated.

A relatively large number of breeds have now been tested for the agreement with the Hardy-Weinberg expectations with regard to the distribution of the genotypes in the FV and $\mathrm{Z}$ systems.

The results from studies of breed samples in which more than 250 cattle were typed are summarised in table 3 . Two of the 16 populations deviated significantly from equilibrium with regard to the FV system. However, the sum of $\chi^{2}$ for all the samples was not significant and there was no trend towards an excess or deficiency of heterozygotes. The results for the $\mathrm{Z}$ system were somewhat different. Agreement with Hardy-Weinberg expectation was tested for both the FV and $\mathrm{Z}$ systems in 7 samples and in all but one of these $\chi^{2} z$ was higher than $\chi_{F V}^{2}$. In 9 of the total of $11 Z$ comparisons there was an excess of heterozygotes, even though only one was so large that the distribution deviated significantly from equilibrium. The sum of $\chi^{2}$ for all the samples was highly significant. The overall result of the population studies for the $\mathrm{Z}$ system indicates the possibility of extra fitness of the heterozygote or a systematic misclassification of a certain proportion of the $\mathrm{Z} / \mathrm{Z}$ homozygotes as $\mathrm{Z} /$ - .

The transferrins. The amount of published segregation data for the cattle transferrins is remarkably large. Ashton (1959) presented results which indicated that the survival of the calf foetus might be influenced by the transferrin types of the dam and its foetus. These results have evidently stimulated compilation of large bodies of segregation data. Ashton (1965) summarised the results of studies published before 1965 and postulated the following effects of transferrins on fitness: (1) superiority of heterozygotes in utero, (2) maternal-foetal incompatibility, (3) differential fertility of heterozygous and homozygous bulls and (4) differential fertility of heterozygous and homozygous cows. It was further suggested that the superiority of the heterozygotes in utero may be sufficient to produce a balanced 
TABLE 3

The observed numbers of heterozygotes in population data as compared to the expected numbers at Hardy-Weinberg equilibrium

\begin{tabular}{|c|c|c|c|c|c|c|c|}
\hline & & & $\begin{array}{l}\text { FV system, No. } \\
\text { of heterozygotes }\end{array}$ & $\begin{array}{c}\chi^{2} \text { for } \\
\text { agreement } \\
\text { with equi- }\end{array}$ & $\begin{array}{l}\text { Z syste } \\
\text { of heter }\end{array}$ & $\begin{array}{l}\text {, No. } \\
\text { sygotes }\end{array}$ & $\begin{array}{l}\quad \chi^{2} \text { for } \\
\text { agreement } \\
\text { with equi- }\end{array}$ \\
\hline Type of data & Source & $\begin{array}{l}\text { Total } \\
\text { No. }\end{array}$ & Obs. $\underbrace{}_{\text {Exp. }}$ & $\begin{array}{l}\text { librium, } \\
1 \text { d.f. }\end{array}$ & Obs. & Exp. & $\begin{array}{l}\text { librium, } \\
1 \text { d.f. }\end{array}$ \\
\hline
\end{tabular}

\section{Breed}

Red Danish, A.I. Neimann-

bulls
$<1$ year
$>1$ year
elite cows
German Fleck-
vieh, bulls
Braunvieh, bulls
Frankenvieh,
bulls
Montbeliarde,
herd data
Friesian, bulls
M.R.Y., bulls
Ayrshire, bulls

Sørensen,

\begin{tabular}{|c|c|c|c|c|c|c|c|}
\hline \multicolumn{8}{|l|}{ Sørensen, } \\
\hline & 289 & 23 & $23 \cdot 9$ & 0.50 & 66 & $61 \cdot 5$ & $1 \cdot 7$ \\
\hline & 793 & 57 & $54 \cdot 9$ & $1 \cdot 10$ & 214 & $202 \cdot 3$ & $2 \cdot 6$ \\
\hline & 289 & 33 & $32 \cdot 9$ & 0.01 & 77 & $78 \cdot 0$ & $0 \cdot 1$ \\
\hline $\begin{array}{l}\text { Buschmann, } \\
1962\end{array}$ & 1000 & 351 & $354 \cdot 7$ & $0 \cdot 10$ & - & - & - \\
\hline $\begin{array}{l}\text { Buschmann, } \\
1962\end{array}$ & 620 & 220 & $221 \cdot 4$ & 0.02 & - & - & - \\
\hline $\begin{array}{l}\text { Buschmann, } \\
1962\end{array}$ & 480 & 127 & $130 \cdot 0$ & 0.25 & 一 & 一 & - \\
\hline $\begin{array}{l}\text { Grosclaude } \\
\text { and Millot, } \\
1962\end{array}$ & 400 & 52 & $58 \cdot 9$ & $5 \cdot 47 *$ & - & - & - \\
\hline Bouw, 1960 & 1200 & 284 & $283 \cdot 8$ & $0 \cdot 00$ & - & - & - \\
\hline Bouw, 1960 & 538 & 140 & $128 \cdot 7$ & $3 \cdot 86^{*}$ & - & - & - \\
\hline $\begin{array}{l}\text { Maijjala and } \\
\text { Lindström, } \\
1966\end{array}$ & 1220 & 365 & $370 \cdot 2$ & $0 \cdot 24$ & - & - & - \\
\hline $\begin{array}{l}\text { Maijala and } \\
\text { Lindström, } \\
1966\end{array}$ & 540 & 170 & $174 \cdot 0$ & $0 \cdot 28$ & - & - & 一 \\
\hline Rendel, 1958 & 630 & 218 & $224 \cdot 3$ & $0 \cdot 50$ & 241 & $235 \cdot 2$ & $0 \cdot 38$ \\
\hline Tolle, 1960 & 682 & 160 & $169 \cdot 3$ & $2 \cdot 00$ & 一 & - & - \\
\hline $\begin{array}{l}\text { Braend et al., } \\
\quad 1962\end{array}$ & 922 & 9 & $11 \cdot 0$ & - & 427 & $411 \cdot 9$ & $0 \cdot 66$ \\
\hline $\begin{array}{l}\text { Braend et al., } \\
\quad 1964\end{array}$ & 1010 & 255 & $256 \cdot 1$ & $0 \cdot 02$ & 228 & $223 \cdot 4$ & $2 \cdot 68$ \\
\hline $\begin{array}{l}\text { Braend et al., } \\
\quad 1964\end{array}$ & 1012 & 56 & $57 \cdot 0$ & - & - & - & - \\
\hline Braend, 1959 & 1000 & 33 & $32 \cdot 6$ & - & 526 & $499 \cdot 8$ & $2 \cdot 75$ \\
\hline Braend, 1959 & 1000 & 142 & $138 \cdot 8$ & 0.53 & 440 & $426 \cdot 2$ & $1 \cdot 05$ \\
\hline $\begin{array}{l}\text { Stormont, } \\
1952\end{array}$ & 1482 & - & - & - & 630 & $645 \cdot 0$ & $1 \cdot 15$ \\
\hline $\begin{array}{l}\text { Stormont, } \\
1952\end{array}$ & 2047 & - & - & - & 1043 & $1021 \cdot 9$ & $0 \cdot 87$ \\
\hline \multirow[t]{2}{*}{ Miller, 1966} & 303 & 77 & $77 \cdot 3$ & 0.00 & 179 & $146 \cdot 4$ & $15 \cdot 10$ **** \\
\hline & 17457 & 2772 & $2799 \cdot 9$ & $\begin{array}{l}14 \cdot 88 \\
\text { (16 d.f.) }\end{array}$ & 4071 & $3951 \cdot 6$ & $\begin{array}{c}29 \cdot 04 \\
(11 \text { d.f. })\end{array}$ \\
\hline
\end{tabular}

Finncattle, bulls

Swedish Red and

Friesian, A.I. bulls

Icelandic cattle, herd data

South West Polled, herd data

Trönder, herd data

Telemark, herd data

Döla, herd data

American Friesian, herd data

American Guernsey, herd data

American Longhorn, herd data

* $\mathrm{P}<0.05$; *** $\mathrm{P}<0.001$. 
TABLE 4

The number of homo- and heterozygous offspring in matings where the unlike-homozygous-mother-effect should not operate, i.e. where the dam is one of the three heterozygous types

\begin{tabular}{|c|c|c|c|c|}
\hline Mating & \multicolumn{2}{|c|}{ Offspring } & \multirow[b]{2}{*}{ Total } & \multirow[b]{2}{*}{ Source } \\
\hline उठ & Homozygous & Heterozygous & & \\
\hline $\mathrm{A} / \mathrm{D} \times \mathrm{A} / \mathrm{D}$ & $\begin{array}{l}63 \\
88 \\
34 \\
11\end{array}$ & $\begin{array}{l}44 \\
75 \\
23 \\
13\end{array}$ & $\begin{array}{r}107 \\
163 \\
57 \\
24\end{array}$ & $\begin{array}{l}\text { Krummen, } 1965 \\
\text { Buschmann, } 1965 \\
\text { Datta et al., } 1965 \\
\text { Jamieson, } 1965\end{array}$ \\
\hline & 196 & 155 & 351 & Sum \\
\hline $\mathrm{A} / \mathrm{A} \times \mathrm{A} / \mathrm{D}$ & $\begin{array}{r}15 \\
3 \\
16\end{array}$ & $\begin{array}{r}14 \\
14 \\
6\end{array}$ & $\begin{array}{l}29 \\
17 \\
22\end{array}$ & $\begin{array}{l}\text { Krummen, } 1965 \\
\text { Buschmann, } 1965 \\
\text { Datta et al., } 1965\end{array}$ \\
\hline & 34 & 34 & 68 & Sum \\
\hline $\mathrm{D} / \mathrm{D} \times \mathrm{A} / \mathrm{D}$ & $\begin{array}{l}33 \\
84 \\
19\end{array}$ & $\begin{array}{l}27 \\
74 \\
19\end{array}$ & $\begin{array}{r}60 \\
158 \\
38\end{array}$ & $\begin{array}{l}\text { Krummen, } 1965 \\
\text { Buschmann, } 1965 \\
\text { Datta et al., } 1965\end{array}$ \\
\hline & 136 & 120 & 256 & Sum \\
\hline $\mathrm{A} / \mathrm{E} \times \mathrm{A} / \mathrm{E}$ & $\begin{array}{r}1 \\
10 \\
4\end{array}$ & $\begin{array}{l}1 \\
7 \\
9\end{array}$ & $\begin{array}{r}2 \\
17 \\
13\end{array}$ & $\begin{array}{l}\text { Jamieson, } 1965 \\
\text { Gahne, } 1961 \\
\text { Brummerstedt-Hansen et al., } 1963\end{array}$ \\
\hline & 15 & 17 & 32 & Sum \\
\hline $\mathbf{A} / \mathrm{A} / \times \mathbf{A} / \mathbf{E}$ & $\begin{array}{r}1 \\
2 \\
25\end{array}$ & $\begin{array}{r}0 \\
2 \\
23\end{array}$ & $\begin{array}{r}1 \\
4 \\
48\end{array}$ & $\begin{array}{l}\text { Buschmann, } 1965 \\
\text { Gahne, 1961 } \\
\text { Brummerstedt-Hansen et al., } 1963\end{array}$ \\
\hline & 28 & 25 & 53 & Sum \\
\hline $\mathrm{E} / \mathrm{E} \times \mathrm{A} / \mathrm{E}$ & 6 & 2 & 8 & Gahne, 1961 \\
\hline $\mathrm{E} / \mathrm{E} \times \mathrm{D} / \mathrm{E}$ & 5 & 2 & 7 & Gahne, 1961 \\
\hline $\mathrm{D} / \mathrm{E} \times \mathrm{D} / \mathrm{E}$ & $\begin{array}{l}0 \\
5 \\
4\end{array}$ & $\begin{array}{l}1 \\
5 \\
4\end{array}$ & $\begin{array}{r}1 \\
10 \\
8\end{array}$ & $\begin{array}{l}\text { Jamieson, } 1965 \\
\text { Gahne, } 1961 \\
\text { Brummerstedt-Hansen et al., } 1963\end{array}$ \\
\hline & 9 & 10 & 19 & Sum \\
\hline $\mathrm{D} / \mathrm{D} \times \mathrm{D} / \mathrm{E}$ & $\begin{array}{r}0 \\
9 \\
11\end{array}$ & $\begin{array}{r}2 \\
12 \\
7\end{array}$ & $\begin{array}{r}2 \\
21 \\
18\end{array}$ & $\begin{array}{l}\text { Krummen, } 1965 \\
\text { Buschmann, } 1965 \\
\text { Brummerstedt-Hansen et al., } 1963\end{array}$ \\
\hline & 20 & 21 & 41 & Sum \\
\hline $\begin{array}{l}\text { Total } \\
\text { Ashton, } 1965\end{array}$ & $\begin{array}{l}449 \\
637\end{array}$ & $\begin{array}{l}386 \\
717\end{array}$ & $\begin{array}{r}835 \\
1354\end{array}$ & \\
\hline Grand total & 1086 & 1103 & 2189 & \\
\hline
\end{tabular}

$\chi^{2}$ Total $=4 \cdot 7 ; 1$ d.f.; $\mathbf{P}=0 \cdot 02-0.05$.

$\chi^{2}$ Ashton $=4.7 ; 1$ d.f.; $\mathbf{P}=0 \cdot 02-0 \cdot 05$.

$\chi^{2}$ Grand total $=0.1 ; 1$ d.f.; $\mathbf{P}=0 \cdot 7-0.8$.

$\chi^{2}$ Heterogeneity, Ashton-Total $=9 \cdot 4 ; 1$ d.f.; $P=0 \cdot 001-0 \cdot 01$. 
polymorphism for the transferrins. The postulates (1) and (2) will be dealt with in this section.

TABLE 5

The unlike-homozygous-mother-effect. Summary of segregating matings involving dams homozygous for transferrins; equal number of homo- and heterozygous offspring to be expected

\begin{tabular}{|c|c|c|c|c|}
\hline Mating & \multirow{2}{*}{$\begin{array}{c}\text { No. of } \\
\text { homozygous }\end{array}$} & \multirow{2}{*}{$\begin{array}{c}\text { No. of } \\
\text { heterozygous }\end{array}$} & \multirow[b]{2}{*}{ Total } & \multirow[b]{2}{*}{ Source } \\
\hline$\sigma^{*} \sigma^{*}$ 우 $\mathrm{h}$ & & & & \\
\hline \multirow[t]{3}{*}{$\mathrm{A} / \mathrm{D} \times \mathrm{D} / \mathrm{D}$} & $\begin{array}{r}82 \\
125 \\
16\end{array}$ & $\begin{array}{l}94 \\
93 \\
11\end{array}$ & $\begin{array}{r}176 \\
218 \\
27\end{array}$ & $\begin{array}{l}\text { Krummen, } 1965 \\
\text { Buschmann, } 1965 \\
\text { Datta et al., } 1965\end{array}$ \\
\hline & 223 & 198 & 421 & Sum \\
\hline & 210 & 168 & 378 & Ashton, 1965 \\
\hline \multirow[t]{2}{*}{$\mathrm{A} / \mathrm{D} \times \mathrm{A} / \mathrm{A}$} & $\begin{array}{r}16 \\
28 \\
8\end{array}$ & $\begin{array}{r}12 \\
23 \\
6\end{array}$ & $\begin{array}{l}28 \\
51 \\
14\end{array}$ & $\begin{array}{l}\text { Krummen, } 1965 \\
\text { Buschmann, } 1965 \\
\text { Datta et al., } 1965\end{array}$ \\
\hline & $\begin{array}{r}52 \\
268\end{array}$ & $\begin{array}{r}41 \\
241\end{array}$ & $\begin{array}{r}93 \\
509\end{array}$ & $\begin{array}{l}\text { Sum } \\
\text { Ashton, } 1965\end{array}$ \\
\hline \multirow[t]{2}{*}{$\mathrm{A} / \mathrm{E} \times \mathrm{E} / \mathbf{E}$} & $\begin{array}{l}2 \\
0\end{array}$ & $\begin{array}{l}1 \\
3\end{array}$ & $\begin{array}{l}3 \\
3\end{array}$ & $\begin{array}{l}\text { Gahne, } 1961 \\
\text { Brummerstedt-Hansen et al., } 1963\end{array}$ \\
\hline & 2 & 4 & 6 & Sum \\
\hline \multirow[t]{2}{*}{$\mathbf{A} / \mathbf{E} \times \mathbf{A} / \mathbf{A}$} & $\begin{array}{r}3 \\
19 \\
17\end{array}$ & $\begin{array}{r}1 \\
18 \\
18\end{array}$ & $\begin{array}{r}4 \\
37 \\
35\end{array}$ & $\begin{array}{l}\text { Buschmann, } 1965 \\
\text { Gahne, } 1961 \\
\text { Brummerstedt-Hansen et al., } 1963\end{array}$ \\
\hline & 39 & 37 & 76 & Sum \\
\hline \multirow[t]{2}{*}{$\mathrm{D} / \mathrm{E} \times \mathrm{D} / \mathrm{D}$} & $\begin{array}{r}2 \\
9 \\
12\end{array}$ & $\begin{array}{r}3 \\
5 \\
10\end{array}$ & $\begin{array}{r}5 \\
14 \\
22\end{array}$ & $\begin{array}{l}\text { Krummen, } 1965 \\
\text { Buschmann, } 1965 \\
\text { Brummerstedt-Hansen } \text { et al., } 1963\end{array}$ \\
\hline & 23 & 18 & 41 & Sum \\
\hline \multirow[t]{2}{*}{$\mathrm{D} / \mathrm{E} \times \mathrm{E} / \mathrm{E}$} & $\begin{array}{l}3 \\
0\end{array}$ & $\begin{array}{l}2 \\
1\end{array}$ & $\begin{array}{l}5 \\
1\end{array}$ & $\begin{array}{l}\text { Gahne, } 1961 \\
\text { Brummerstedt-Hansen } \text { et al., } 1963\end{array}$ \\
\hline & 3 & 3 & 6 & Sum \\
\hline $\begin{array}{l}\text { Total this study } \\
\text { Ashton, } 1965\end{array}$ & $\begin{array}{l}342 \\
478\end{array}$ & $\begin{array}{l}301 \\
409\end{array}$ & $\begin{array}{l}643 \\
887\end{array}$ & \\
\hline Grand total & 820 & 710 & 1530 & \\
\hline
\end{tabular}

Ashton found that in matings between heterozygous sires and homozygous dams (e.g. A/D $\hat{\sigma} \widehat{\sigma} \times \mathrm{D} / \mathrm{D}$ 우우) there was a significant excess of offspring like the mother while in the reciprocal matings there was an excess of heterozygotes and also in the matings between $A / D$ heterozygotes. The 
latter was presumed to be due to superior viability of the heterozygote in utero and the former was ascribed by Ashton to maternal-foetal incompatibility. Such interaction is well documented for some red cell antigens in

TABLE 6

$A$ comparison of the segregation ratios in $D / D \delta^{*} \sigma^{*} \times A / D$ 우우 and $A / D \delta^{*} \sigma^{*} \times D / D$ 우우 matings tested in the same laboratories

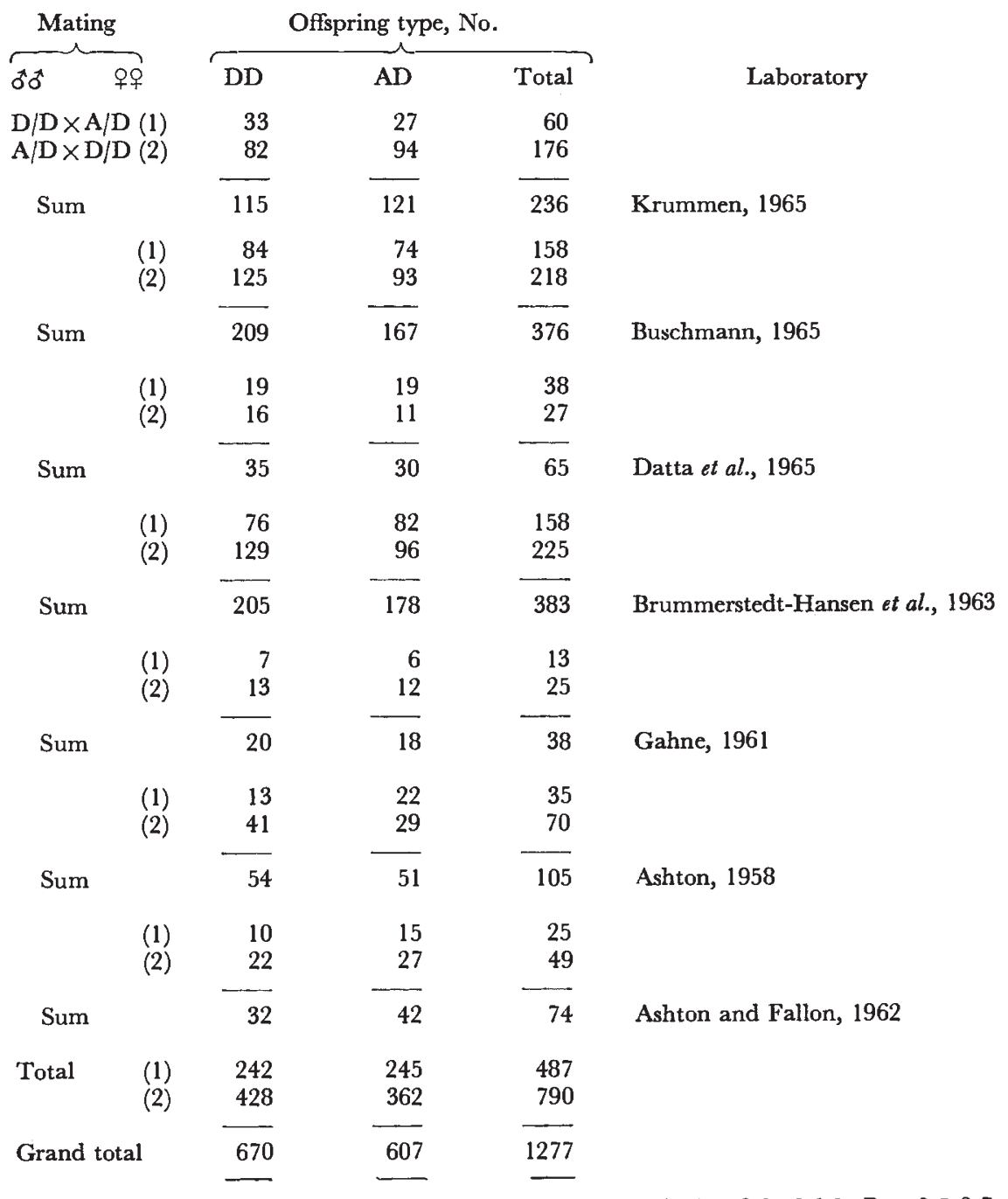

Heterogeneity between laboratories, segregation for mating (1) $\chi^{2}=3.9 ; 6$ d.f.; $\mathbf{P}=0.5-0 \cdot 7$. Heterogeneity between laboratories, segregation for mating (2) $\chi^{2}=8 \cdot 4 ; 6$ d.f.; $\mathrm{P}=0 \cdot 2-0 \cdot 3$. Heterogeneity between total (1) and total (2) $\chi^{2}=2 \cdot 4 ; 1$ d.f.; $P=0 \cdot 1-0 \cdot 2$.

Deviation from $1: 1$ in total (2) $\chi^{2}=5.5 ; 1$ d.f.; $P=0.01-0.02$.

several species. The term incompatibility implies some immunological mechanism for which there is so far no evidence with regard to the transferrins. Therefore the more neutral term unlike-homozygous-mother or "UHM effect" will be used here. 
Segregation ratios for transferrins are now available in a number of publications in addition to those reviewed by Ashton (1965). The results of these additional matings involving heterozygous dams are presented in table 4. The matings for which an UHM effect is possible are summarised in table 5. As seen from table 4, Ashton's postulate of a superiority of the heterozygote in utero could not be verified here. There was a significant

TABLE 7

The expected and observed frequencies of heterozygosity for transferrins in population studies

\begin{tabular}{|c|c|c|c|c|c|c|}
\hline \multirow[b]{2}{*}{ Breed and type of sample } & \multirow{2}{*}{$\begin{array}{l}\text { Total } \\
\text { No. }\end{array}$} & \multicolumn{2}{|c|}{$\begin{array}{c}\text { No. of } \\
\text { heterozygotes }\end{array}$} & \multirow{2}{*}{$\begin{array}{c}\chi^{2} \text { for } \\
\text { agreement } \\
\text { with Hardy- } \\
\text { Weinberg } \\
\text { distribution }\end{array}$} & \multirow[b]{2}{*}{ D.F. } & \multirow[b]{2}{*}{ Source } \\
\hline & & Obs. & Exp. & & & \\
\hline Swedish Red and White, bulls & 404 & 236 & $243 \cdot 9$ & $1 \cdot 8$ & 3 & Gahne, 1961 \\
\hline Finnish Ayrshire, herd data & 4040 & 2154 & $2170 \cdot 0$ & $9 \cdot 5^{*}$ & 3 & Vasenius, 1965 \\
\hline $\begin{array}{l}\text { Red Danish, cows from } \\
\text { random herds }\end{array}$ & 1128 & 681 & $679 \cdot 5$ & $0 \cdot 4$ & 3 & $\begin{array}{l}\text { Brummerstedt-Hansen } \\
\text { et al., } 1963\end{array}$ \\
\hline $\begin{array}{l}\text { Danish Friesian, cows from } \\
\text { random herds }\end{array}$ & 576 & 300 & $303 \cdot 8$ & $1 \cdot 5$ & 2 & $\begin{array}{l}\text { Brummerstedt-Hansen } \\
\quad \text { et al., } 1963\end{array}$ \\
\hline $\begin{array}{l}\text { ersey, cows from random } \\
\text { herds }\end{array}$ & 425 & 185 & $175 \cdot 4$ & $1 \cdot 2$ & 1 & $\begin{array}{l}\text { Brummerstedt-Hansen } \\
\text { et al., } 1963\end{array}$ \\
\hline ersey, A.I. cows & 375 & 199 & $186 \cdot 1$ & $1 \cdot 8$ & 1 & Ashton and Fallon, 1962 \\
\hline $\begin{array}{l}\text { Illawarra Shorthorn, herd } \\
\text { data }\end{array}$ & 622 & 356 & $325 \cdot 2$ & $16 \cdot 4 * * *$ & 3 & Ashton and Fallon, 1962 \\
\hline $\begin{array}{l}\text { Hungarian Spotted, herd } \\
\text { data }\end{array}$ & 631 & 262 & $264 \cdot 7$ & $1 \cdot 5$ & 2 & Márkus et al., 1964 \\
\hline $\begin{array}{l}\text { German Fleckvieh, parentage } \\
\text { data }\end{array}$ & 3347 & 950 & $941 \cdot 7$ & $0 \cdot 3$ & 2 & Buschmann, 1965 \\
\hline $\begin{array}{l}\text { German Braunvieh, parentage } \\
\text { data }\end{array}$ & 731 & 312 & $319 \cdot 5$ & 0.7 & 2 & Buschmann, 1965 \\
\hline $\begin{array}{l}\text { German Friesian, parentage } \\
\text { data }\end{array}$ & 675 & 319 & $365 \cdot 9$ & $13 \cdot 9 * *$ & 2 & Buschmann, 1965 \\
\hline immentaler, parentage data & 1020 & 337 & $337 \cdot 7$ & $0 \cdot 1$ & 1 & Krummen, 1965 \\
\hline riburger, parentage data & 397 & 152 & $158 \cdot 2$ & $0 \cdot 6$ & 1 & Krummen, 1965 \\
\hline celandic cattle, herd data & 941 & 437 & $437 \cdot 5$ & $0 \cdot 3$ & 2 & Braend et al., 1965 \\
\hline Imerican Friesian, one herd & 332 & 168 & $166 \cdot 7$ & $0 \cdot 0$ & 1 & Datta et al., 1965 \\
\hline British Friesian, A.I. bulls & 414 & 236 & $275 \cdot 0$ & $25 \cdot 5 * *$ & 9 & Jamieson, 1966 \\
\hline \multirow[t]{2}{*}{ British Ayrshire, cows } & 491 & 322 & $342 \cdot 0$ & $6 \cdot 4$ & 9 & Jamieson, 1966 \\
\hline & 16550 & 7606 & $7692 \cdot 8$ & $82 \cdot 0$ & 47 & \\
\hline
\end{tabular}

deviation from the expected 1:1 ratio though this was in the opposite direction to that of Ashton. If the two sets of data are pooled an almost perfect $1: 1$ ratio is obtained. The ratios for the segregating matings where the UHM effect is possible go in the same direction in both Ashton's and the present data. There is a significant excess of homozygotes like the mother. The pooling of data from many laboratories would be hazardous if systematic typing errors occurred. The A/D and D/D types are sometimes difficult to distinguish from one another. Segregation ratios based on the $A / D$ and $D / D$ types may therefore be affected by systematic differences between laboratories. In order to minimise this possible source of error the results of the compatible mating $(\mathrm{D} / \mathrm{D} \delta \approx \times \mathrm{A} / \mathrm{D}$ 우, mating type 1 and the 
corresponding incompatible one $\mathrm{A} / \mathrm{D} \hat{\jmath} \hat{\partial} \times \mathrm{D} / \mathrm{D}$ 우의, mating 2) were compared within laboratories. As seen from table 6, there was no significant heterogeneity between laboratories for either mating. However, there was a significant excess of homozygotes $(\mathrm{D} / \mathrm{D})$ and this was entirely due to the segregation in the matings where an UHM effect is possible.

The agreement of the transferrin type distribution with the HardyWeinberg expectations has been investigated in numerous populations. Table 7 summarises the results obtained in 17 breed samples with at least 300 tested animals. The deviation from genetic equilibrium was significant in 4 of the samples. In one there was a significant excess of heterozygotes and in the remaining there was a surplus of homozygotes. The total number of homozygotes was slightly higher than the expected number summed over all breeds.

Ashton and Fallon (1962), who compared the observed and expected frequency of transferrin heterozygotes in several populations, two of which are included in our table 7, found an excess of about 6 per cent. of heterozygotes. Ashton (1965) compared the number of observed and expected heterozygotes for transferrins and postalbumins in 6 small African breed samples and in 4 small Australian samples. There was an overall excess of 5.5 per cent. heterozygotes for transferrins and 2.5 per cent. heterozygotes for the postalbumins. Ashton apparently regards the slightly higher excess of heterozygotes in the transferrin system as evidence for a selective advantage of transferrin heterozygotes. The strength of such evidence is difficult to assess because no statistical test was provided to measure the significance of he difference.

\section{RESUltS FROM INGOMPLETE FAMILY DATA (I.F.D.) AND OUR OWN POPULATION STUDIES}

In tables 8 and 9 the I.F.D. for the FV, $\mathrm{Z}$ and transferrin systems are given. All our own data relate to male parents and their male offspring. The transferrin tested sample from this laboratory is rather small. Table 9 also includes a larger body of data published by Brummerstedt-Hansen et al. (1963) but not analysed by them. These data were derived from male parents and their female offspring. The offspring were all pure bred; 63 per cent. belonged to the Red Danish (RDM), 24 per cent. to the Danish Friesian (SDM) and 13 per cent. to the Danish Jersey breed.

In table 10 the data in tables 8 and 9 are tested for agreement with the expected $1: 1$ ratios. There are no significant departures and so no indication of any differences in viability.

In table 11 data are presented on the genotypic numbers for the total population of bulls born in 1940-66 and tested in this laboratory. The distributions are in good agreement with the Hardy-Weinberg expectations.

The female gametic gene ratios ( $c f$. table 2) are tested for heterogeneity in table 12. For the FV and $\mathrm{Z}$ systems there are no significant departures, so there is no indication of viability differences between genotypic classes or any suggestion of heterogeneity of gene frequencies in the population. However, when one turns to the figures in table 13 there is an apparent contradiction. There is significant temporal heterogeneity of gene frequency both for the FV system and the $\mathcal{T} f^{D}$ and $\mathcal{T} f^{E}$ alleles in the transferrin system. 
For the FV system this heterogeneity is partly ascribable to the trend in gene frequency. The difference between the average gene frequencies for 1940-58 and 1959-66 is highly significant. For $\mathcal{T f}^{E}$ the difference between these two periods is just significant but for $\mathcal{T f}^{D}$ most of the heterogeneity is not due to

TABLE 8

Incomplete family data for the $F V$ and $Z$ systems

\begin{tabular}{crrr} 
& \multicolumn{3}{c}{ Sons' type } \\
\cline { 3 - 4 } Sires' type & $\overbrace{\mathbf{V} / \mathbf{V}}$ & $\mathbf{F} / \mathbf{V}$ & $\mathbf{F} / \mathbf{F}$ \\
V/V & 10 & 31 & - \\
$\mathbf{F} / \mathbf{V}$ & 75 & 297 & 268 \\
$\mathbf{F} / \mathbf{F}$ & - & 276 & 996 \\
& $-1-$ & $\mathbf{Z} /-$ & $\mathbf{Z} / \mathbf{Z}$ \\
& & & \\
$-/-$ & 768 & 265 & - \\
$\mathbf{Z} /-$ & 326 & 417 & 103 \\
$\mathbf{Z} / \mathbf{Z}$ & - & 56 & 18
\end{tabular}

TABLE 9

Incomplete family data for the transferrin system

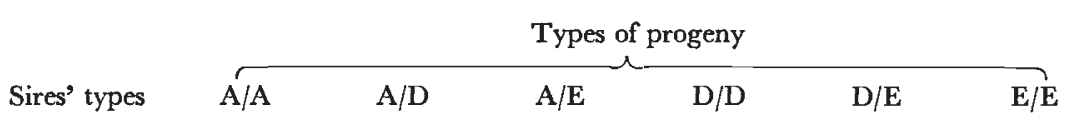

(1) This investigation

\begin{tabular}{lrrrrrr} 
A/A & 125 & 39 & 51 & 0 & 0 & 0 \\
A/D & 33 & 33 & 17 & 9 & 20 & 0 \\
A/E & 53 & 16 & 66 & 0 & 14 & 29 \\
D/D & 0 & 8 & 0 & 0 & 4 & 0 \\
D/E & 0 & 10 & 14 & 2 & 10 & 2 \\
E/E & 0 & 0 & 21 & 0 & 4 & 17 \\
\cline { 2 - 7 } & 211 & 106 & 169 & 11 & 52 & 48 \\
\hline
\end{tabular}

(2) Brummerstedt-Hansen et al., 1963

\begin{tabular}{lcrrrrr} 
A/A & 241 & 206 & 41 & $(1) \dagger$ & $(1) \dagger$ & 0 \\
A/D & 260 & 469 & 41 & 190 & 45 & 0 \\
A/E & 27 & 37 & 38 & 0 & 32 & 11 \\
D/D & $(4) \dagger$ & 179 & $(1) \dagger$ & 145 & 23 & 0 \\
D/E & 0 & 19 & 31 & 11 & 21 & 3 \\
E/E & 0 & 0 & 0 & 0 & 0 & 0 \\
\hline & 532 & 910 & 152 & 347 & 122 & 144 \\
\hline
\end{tabular}

$\uparrow$ Offspring's type not in accord with genetic theory.

any trend. The heterogeneity of gene frequency in the transferrin system is reflected by a highly significant heterogeneity of female gametic gene ratios for $\mathcal{T f}^{D}\left(\chi^{2}=27 \cdot 5\right.$; table 12). The sires which carried the $\mathcal{T} f^{D}$ gene were mated to females where the gametic output of the $T f^{D}$ and $\left(\mathcal{T} f^{A}+\mathcal{T} f^{E}\right)$ occurred in a ratio of approximately $1: 2$ while the corresponding ratio for the mates of the sires lacking the $T f^{D}$ gene was $1: 5$. There was evidently a stratification of the breed with regard to the occurrence of the $\mathcal{T f}^{D}$ gene. 
Despite the time trend and heterogeneity of gene frequency the genotypic distributions of all three systems showed good agreement with HardyWeinberg expectations for the total frequencies between 1940 and 1966. Tests were also performed for each single year or in case of small numbers on pooled data from adjacent years. In one single case only a significant

TABLE 10

$\chi^{2}$ tests on expected 1:1 ratios in incomplete family data for cattle transferrins and the $F V$ and $Z$ systems; data derived from tables 8 and 9

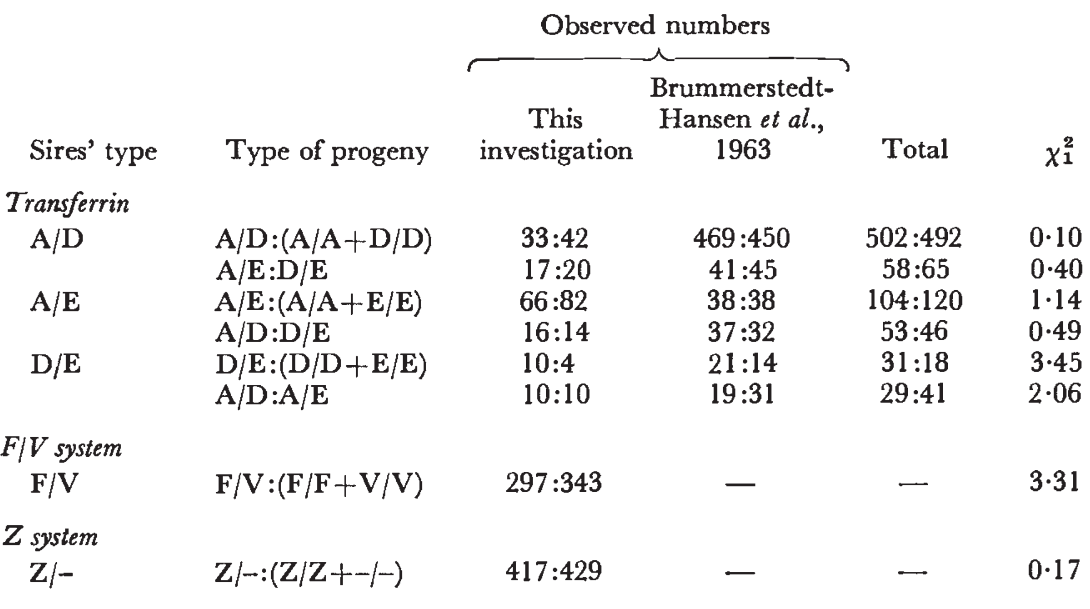

TABLE 11

The genotypic distributions in the $F V, Z$ and transferrin systems and the respective Hardy-Weinberg expectations

\begin{tabular}{|c|c|c|c|c|c|c|c|c|c|}
\hline & \multirow{2}{*}{$\begin{array}{c}\text { Total } \\
\text { No. }\end{array}$} & \multicolumn{4}{|c|}{ FV system } & \multicolumn{4}{|c|}{ Z system } \\
\hline & & FF & FV & VV & $\chi_{1}^{2}$ & $-1-$ & $\mathbf{Z} /-$ & $\mathrm{Z} / \mathrm{Z}$ & $x_{1}^{2}$ \\
\hline Obs. & 2897 & 1872 & 904 & 121 & \multirow{2}{*}{$\begin{array}{l}0.8 \\
P>0.3\end{array}$} & 1600 & 1127 & 170 & \multirow{3}{*}{$\begin{array}{l}2 \cdot 38 \\
P>0 \cdot 1\end{array}$} \\
\hline \multirow[t]{3}{*}{ Exp. } & 2897 & $1864 \cdot 3$ & $919 \cdot 3$ & $113 \cdot 3$ & & $1615 \cdot 7$ & $1095 \cdot 6$ & $185 \cdot 7$ & \\
\hline & & \multicolumn{7}{|c|}{ Transferrin system } & \\
\hline & No. & AA & EE & DI & $\mathrm{AE}$ & $\mathrm{AD}$ & $\mathrm{DE}$ & & $\chi_{3}^{2}$ \\
\hline Obs. & 1685 & 556 & 131 & 49 & 517 & 279 & 153 & \multirow{2}{*}{\multicolumn{2}{|c|}{$4.1 ; P>0$}} \\
\hline Exp. & 1685 & $540 \cdot 2$ & $128 \cdot 9$ & 41 & $527 \cdot 8$ & 300 & $146 \cdot 5$ & & \\
\hline
\end{tabular}

deviation was indicated ( $T f$-system in $\left.1953 \chi_{1}^{2}=3.94\right)$. However, total $\chi^{2}$ for agreement within years was non-significant (table 13).

The female gametic gene ratios for the transferrin system in the data of Brummerstedt-Hansen et al. are also tested for heterogeneity in table 12. The ratios for $T f^{E}$ show highly significant heterogeneity, $T f^{D}$ is not significantly heterogenous, but the value of $\chi^{2}$ is quite large $\left(\chi_{2}^{2}=5 \cdot 42\right.$; $\mathbf{P}=0 \cdot 05-0 \cdot 10)$ and $T f^{A}$ is not heterogenous at all. The results are rather to be expected from the breed composition of the sample. The RDM, 
TABLE 12

$\chi^{2}$ tests for heterogeneity of the female gametic gene ratios for the transferrin, $F V$ and $Z$ systems

System and ratio $\quad$ Source of data $\quad \begin{gathered}\text { Total } \\ \text { observed } \\ \text { gametic ratio }\end{gathered} \begin{gathered}\text { Heterogeneity } \\ \chi_{2}^{2}\end{gathered}$

$T f^{A}$ versus its absence, i.e. $T f^{A}$ :

$\left(T f^{E}+T f^{D}\right)$ in the offspring

from $\mathrm{A} / \mathrm{A}, \mathrm{A} /+$ and $+1+$ sires

Tf ${ }^{E}$ versus its absence, etc.

$T f^{D}$ versus its absence, etc.

This paper

$264: 201$

$0 \cdot 54$

This paper

$136: 353$

$114: 440$

$3 \cdot 75$

This paper

$757: 728$

$27 \cdot 53 * *$

Tf ${ }^{\wedge}$ versus its absence, etc.

Brummerstedt-

hansen et al., 1963

Brummerstedt-

hansen et al., 1963

Brummerstedt

hansen et al., 1963

$621: 895$

$1 \cdot 52$

$5 \cdot 42$

$227: 1784$

$112 \cdot 62 * * *+$

This paper

$361: 1295$

$0 \cdot 20$

This paper

$1150: 386$

$0 \cdot 55$

$Z(Z$ versus $z$,

$\dagger$ One degree of freedom only.

** $\mathrm{P}<0.01$. **** $\mathrm{P}<0.0001$.

TABLe 13

Heterogeneity of gene frequency with time (measured per year $\dagger$ between 1940-66) and its effect upon Hardy-Weinberg expectations; degrees of freedom in brackets

\begin{tabular}{|c|c|c|c|c|c|}
\hline \multirow[b]{2}{*}{$\chi^{2}$ test and gene frequency } & \multirow{2}{*}{$\begin{array}{l}\text { FV } \\
F^{F}\end{array}$} & \multirow{2}{*}{$\begin{array}{l}\mathrm{Z} \\
\mathrm{Z}\end{array}$} & \multicolumn{3}{|c|}{ Transferrin } \\
\hline & & & $T f^{A}$ & $T f^{D}$ & $T_{f^{E}}$ \\
\hline $\begin{array}{l}\text { Heterogeneity of gene frequency } \\
\text { between years for bulls born } \\
\text { 1940-66 }\end{array}$ & $\begin{array}{l}63 \cdot 26 * * * \\
(17)\end{array}$ & $\begin{array}{c}14 \cdot 50 \\
(17)\end{array}$ & $\begin{array}{c}15 \cdot 59 \\
(15)\end{array}$ & $\begin{array}{c}25 \cdot 83 * \\
(15)\end{array}$ & $\begin{array}{l}31 \cdot 31 * * \\
(15)\end{array}$ \\
\hline $\begin{array}{l}\chi^{2} \text { for difference between gene } \\
\text { frequencies in } 1940-58 \text { and } \\
1959-60\end{array}$ & $\begin{array}{l}21 \cdot 82^{* * *} \\
(1)\end{array}$ & $\begin{array}{l}0 \cdot 00 \\
(1)\end{array}$ & $\begin{array}{l}3 \cdot 25 \\
(1)\end{array}$ & $\begin{array}{l}0 \cdot 00 \\
(1)\end{array}$ & $\begin{array}{l}3 \cdot 90^{*} \\
(1)\end{array}$ \\
\hline $\begin{array}{l}\text { Gene frequency } 1940-66 \\
\text { Gene frequency } 1940-58 \\
\text { Gene frequency } 1959-66\end{array}$ & $\begin{array}{l}0 \cdot 802 \\
0 \cdot 784 \\
0 \cdot 827\end{array}$ & $\begin{array}{l}0 \cdot 253 \\
0 \cdot 251 \\
0 \cdot 256\end{array}$ & $\begin{array}{l}0.566 \\
0.544 \\
0.577\end{array}$ & $\begin{array}{l}0 \cdot 157 \\
0 \cdot 158 \\
0 \cdot 157\end{array}$ & $\begin{array}{l}0 \cdot 277 \\
0 \cdot 299 \\
0 \cdot 266\end{array}$ \\
\hline $\begin{array}{l}\text { Agreement of total numbers for } \\
1940-66 \text { with Hardy-Wein- } \\
\text { berg expectations, } \chi^{2}\end{array}$ & $\begin{array}{l}0 \cdot 81 \\
(1)\end{array}$ & $\begin{array}{l}2 \cdot 38 \\
(1)\end{array}$ & & $\begin{array}{l}3 \cdot 729 \\
(3)\end{array}$ & \\
\hline $\begin{array}{l}\text { Sum of } \chi^{2} \text { for agreement with } \\
\text { Hardy-Weinberg for numbers } \\
\text { within each year from } 1940 \\
\text { to } 1966\end{array}$ & $\begin{array}{c}11 \cdot 50 \\
(18)\end{array}$ & $\begin{array}{c}14 \cdot 41 \\
(18)\end{array}$ & & $\begin{array}{c}70 \cdot 39 \\
(54)\end{array}$ & \\
\hline Total numbers & 289 & & & 1685 & \\
\hline
\end{tabular}

$\dagger$ Except when numbers were too small, then pooled.

* $\mathrm{P}<0.05$. ** $\mathrm{P}<0.01$. *** $\mathrm{P}<0.001$. 
SDM and Jersey breeds have the following gene frequencies. Tf $A 0 \cdot 472$, 0.452 and $0.761 ; T f^{D} 0.395,0.502$ and 0.286 ; and $T f^{E} 0.132,0.030$ and 0.002 respectively. Despite the fact that the sample of offspring was composed of a mixture of three breeds, the pooled distribution of genotypes did not deviate significantly from the Hardy-Weinberg expectation $\left(\chi_{3}^{2}=2 \cdot 3\right.$; $\mathrm{P}=0.5)$. However, the heterogeneity was easily revealed by the I.F.D. technique described here.

\section{Discussion}

The family data of both kinds (I.F.D. and C.F.D.) and the population data for the two red cell antigenic loci are essentially in agreement with their respective expectations. The only exception is the population data for the American Longhorn, where there is an excess of heterozygotes (Miller, 1966). These data stem from a small closed herd and so the most probable explanation is the Robertson effect. Selection for heterozygotes or misclassification of $\mathrm{Z} / \mathrm{Z}$ as $\mathrm{Z} /$ - are possible, since $\mathrm{Z} / \mathrm{Z}$ is recognised by a dosage reagent. The latter seems unlikely but the possibility of selection for heterozygotes should be entertained a little further. Of the 11 samples for $\mathrm{Z}, 9$ show an excess of heterozygotes. However, the I.F.D. 1:1 ratio does not.

Despite the fact that the FV and $\mathrm{Z}$ systems have been known for a decade longer than the transferrin polymorphism there exists a great deal more published family data for the latter. Much data for FV and $\mathrm{Z}$ probably remain unexamined in blood group laboratories. As a result of Ashton's proposals (see Ashton, 1965, for a summary of his viewpoint) a number of workers have gathered and published segregation data for transferrins. Here we have summarised what we believe is all larger bodies of published material. The unlike-homozygous mother effect for $\mathrm{A} / \mathrm{A}$ and $\mathrm{D} / \mathrm{D}$ mothers in matings with $\mathrm{A} / \mathrm{D}$ sires seems to exist. The tendency is consistently present in nearly all the data. No trivial explanation in terms of typing error seems possible. The underlying biological mechanism is unknown. The reciprocal matings give the expected Mendelian ratios.

There is less support for the notion of a selective advantage of heterozygotes through differential viability either in utero or at any other time during the life history of the animal. Ashton (1965) summarised a number of studies and found that in segregating matings where the unlike-homozygous mother or UHM effect cannot occur, i.e. in A/D 우 by A/A, A/D or D/D ôt a significant excess of heterozygotes existed. In our more complete survey this is not so. There is close agreement with expectation. This is also mainly true of the population data except for one population where there is a clear excess of heterozygotes and another two where there are deficiencies. These latter are probably due to variance in gene frequency between subpopulation, Wahlund's effect. This effect will cause an apparent deficiency of the number of heterozygotes, tending to nullify the effect of any selective advantage for heterozygotes, so that the population data are not very critical. Above we have recommended the use of I.F.D. to separate Wahlund's effect and the effect of selection. However, in this case the combination of the existence of the UHM effect and the fact that cattle I.F.D. are in the form of sire groups makes the interpretation of the results for I.F.D. difficult. For the expected 1:1 ratio of heterozygotes to corresponding homozygotes, the UHM effect will produce a deficiency of heterozygotes from male parents. That it does not do so in this case (table 10) 
could be taken as evidence of selective advantage for the heterozygotes but it is more likely to be due to the relatively small magnitude of the UHM effect and the small numbers contributing to the observed ratio. Considering the entirety of the data, it is clear that any viability advantage for the heterozygotes must be a small one, if it exists at all. As already pointed out, Ashton has postulated some rather complicated associations between transferrin type and fertility. Ashton's argument for the existence of these associations must be discussed since they make the assumption that there is no heterogeneity of gene frequency in his populations. Ashton found a slight excess of transferrin homozygotes among bulls standing at A.I. centres, which was taken as evidence for higher fertility of homozygotes. However, the possibility should not be overlooked that the departures from HardyWeinberg equilibrium might have been due to Wahlund's effect, particularly as no data were given for bulls which were rejected by the A.I. service. In at least one of the breeds concerned, the British Friesian, Wahlund's effect has been found to operate (Jamieson, 1966). Similar observations apply to Ashton's data associating various parameters of fertility and transferrin type (table 6; Ashton, 1965). The data do not allow spurious associations between fertility and transferrin type to be excluded. In a recent study Gahne (1968) found no indication whatsoever of an effect of transferrin type on fertility. Ashton placed considerable weight upon differences which are quite non-significant. For example, his assertion that homozygous cows are more fertile appears to be based upon a difference giving a $\chi^{2}$ of $1 \cdot 58$. The only effect of the transferrins for which the evidence is good is the unlike homozygous mother effect in $\mathrm{A} / \mathrm{A}$ and $\mathrm{D} / \mathrm{D}$ mothers and this makes the transferrin polymorphism seem more like an unstable one. The analogy of the $\mathrm{Rh}$ system is obvious.

In our own data there was temporal heterogeneity of the gene frequency for the FV and transferrin systems. For FV this was partly the result of a trend in gene frequency with time but for transferrin no strong trend was evident. A great deal of this heterogeneity would disappear if allowance were made for the degree of relatedness in the population. Pooling data from different years with differing gene frequencies is equivalent to pooling data from different populations and so should lead to Wahlund's effect. In fact, it did not. For the FV system which had the largest heterogeneity, $\chi^{2}$, the variance in gene frequency between years was 0.0017. (This estimate was based on the gene frequencies for the single years except for 1940-44, 1945-49 and 1965-66 where poolings were made. The difference in numbers per year was ignored.) Thus the Hardy-Weinberg expectations for the FV system (table 11) need only be modified by adding $0.0017 \times 2897=4.91$ to the two homozygous classes and subtracting twice that from the heterozygous class, a modification which is insignificant. In both our own data and those of Brummerstedt-Hansen et al. there was a significant heterogeneity of the female gametic gene ratios for transferrins. In the latter sample heterogeneity would be expected on the basis of the gene frequencies in the three breeds of which the sample was composed. The heterogeneity in our own data suggests a stratification of the SRB breed with regard to the distribution of transferrin genes. It is interesting that despite the large values of $\chi^{2}$ for heterogeneity of female gametic transferrin gene ratios in the two samples, there were no significant departures from the Hardy-Weinberg expectation in either case. The customary test for agreement with the Hardy-Weinberg 
distribution is evidently rather inefficient in detecting stratification of breeding populations.

Finally we may note that in our analysis the rarer genes ( $T f^{D}$ in the SRB and $T f^{E}$ in the Danish cattle) showed heterogeneity in the I.F.D. whereas the other more common ones did not. The reason for this can be found in table 1. Heterogeneity of gene frequency causes a much greater relative alteration to the expected values of the less frequent phenotypic classes than to those of the more frequent. That is, the effect of heterogeneity of gene frequency upon blood type frequencies in cattle populations is very similar to the effect of inbreeding upon the frequency of rare recessive phenotypes in man.

\section{SUMMARY}

1. Cattle blood group laboratories tend to accumulate data on the blood types of one parent and a number of its progeny, e.g. when a sire and his sons are typed for registration purposes. Such data are referred to as incomplete family data (I.F.D.), as distinct from complete family data (C.F.D.), and population data (P.D.).

2. For P.D., two sorts of gene frequency heterogeneity (Wahlund's effect and Robertson's effect) can lead to departure from Hardy-Weinberg expectations in cattle populations without there being any selective differences between genotypes.

3. A simple analysis of I.F.D. allows the effects of selection and gene frequency heterogeneity to be separated. This is not so for P.D., which are much more often analysed and published for cattle blood groups.

4. Analyses of I.F.D. and P.D. for the FV and $\mathrm{Z}$ red cell antigen groups and the serum transferrin (Tf) locus for data from the Swedish Red and White Breed (SRB) are interpreted in association with other published P.D., I.F.D. and C.F.D. for these systems.

5. There is no evidence for selection at the FV and $\mathrm{Z}$ loci.

6. Published C.F.D. for the $T f$ locus agree with a previous suggestion that $T f^{A} T f^{D}\left(\delta^{D} \delta^{D}\right) \times T f^{D} T f^{D}$ (우) matings tend to give more $T f^{D} T^{D}$ offspring than expected. There is, however, no convincing evidence for a superior selective advantage for heterozygotes at the cattle $T f$ locus.

7. Heterogeneity of the frequency of $T f^{D}$ was found in the I.F.D. for the SRB and for $T f^{E}$ in data from a mixture of Danish breeds. This heterogeneity was not detected in the P.D., which suggests that I.F.D. are more sensitive to such heterogeneity.

8. Examination of the gene frequencies in bulls in different years showed significant heterogeneity for gene frequency between years for the $\mathrm{FV}$ and $T f$ systems. For FV there was a gene frequency trend with time.

Acknowledgment.-Mr K. Ölmestrand, head of the data processing centre, College of Agriculture, gave generous help in writing programmes for the Control-Data, 3600 computer used in the analyses.

\section{References}

Ashton, G. G. 1959. $\beta$-globulin polymorphism and early foetal mortality in cattle. Nature, 183 (4658), 404-405.

Ashton, G. C., 1965. Cattle serum transferrins : a balanced polpmorphism? Genetics, 52, 983-997.

ASHTON, G. C., AND FALlon, G. R. 1962. $\beta$-globulin type, fertility and embryonic mortality in cattle. 7. Reprod. Fertil., 3, 93-104. 
Bouw, J. 1960. The genetical composition of the Dutch cattle breeds as determined by the frequencies of blood groups. Z. Tierz. u. Zücht. biol., 74, 248-266.

BRAEND, M. 1959. Blood Groups of Cattle in Norway. Skandinavisk Bladforlag, 144 pp.

BRAEND, M., BERG, I. H., AND LIE, H. 1964. Blood groups of Norwegian cattle. Studies on South and West Norway cattle (SV) and Coloursided Trønder cattle(ST). Acta Agriculturae, 14, 150-164.

BRAend, M., Rendel, J., GAHNE, B., AND AdAlsteinsson, s. 1962. Genetic studies on blood groups, transferrins and hemoglobins in Icelandic cattle. Hereditas, 48, 264-283.

BRUMMERSTEDT-HANSEN, E., MOUSTGAARD, J., AND MøLlER, I. 1963. Serum-transferrinpolymorphism in Danish cattle breeds. Yearbook of Royal Vet. and Agr. Coll., Copenhagen, 13-26.

BUSCHMANN, H. 1962. Blutgruppengenetische Untersuchungen an süddeutschen Rinderrassen. Z. Tierz. u. Zücht. biol., 78(1), 12-25.

BUSCHMANN, H. 1965. Untersuchungen über die Vererbung der Serumtransferrin und Hämoglobineigenschaften beim Rind. Z. Tierz. u. Zücht. biol., 81, 204-215.

coHen, c. 1962. Blood groups in infrahuman species. Annals N.Y. Acad. Sci., 97, 1.

COOPER, D. w. 1966. A note on the examination of genotypic ratios in domestic animals using incomplete family data. Animal Production, 8, 511-513.

DATTA, S. P., STONE, W. H., TYLER, W. J., AND IRWIN, M. R. 1965. Cattle transferrins and their relation to fertility and milk production. Genetics, 24, 313-318.

GAHne, B. 1961. Studies of transferrins in serum and milk of Swedish cattle. Animal Production, 3, 135-145.

GAHNE, B. 1968. Transferrin variation in cattle, segregation ratios and influence on fertility. Acta Agr. Scand. (In the press.)

grosclaude, F. 1967. Editor, Polymorphismes biochemiques des Animaux. Proceedings Xth European Conference on Animal Blood Group Research. Institut national de la Agronomique, Paris, 577 pp.

grosclaude, F., AND millot, P. 1962. Contribution a l'étude des groupes sanguins de la race bovine Montbéliarde. Ann. Biol. Anim. Bioch. Biophys., 2(3), 185-208.

JAMIESON, A. 1965. The genetics of transferrins in cattle. Heredity, 20, 419-441.

JAMIESON, A. 1966. The distribution of transferrin genes in cattle. Heredity, 21, 191-218.

KIDDY, A. c. 1964. Inherited differences in specific blood and milk proteins in cattle; a review. 7. Dairy Sci., 47(5), 510-515.

KRUMMEN, H. 1965. Bestimmung der Serumtransferrin- und Haemoglobintypen bei den schweizerischen Rinderrassen. Z. Tierz. u. Zücht. biol., 81(2), 139-166.

MAIJALA, K. 1966. On the possibility of predicting the success of a bull's daughters from his blood type. Ann. Agr. Fenniae, 5, 65-70.

MAIJALA, K., AND LINDSTRÖM, G. 1966. Frequencies of blood group genes and factors in the Finnish cattle breeds with special regard to breed comparisons. Ann. Agr. Fenniae, 5, $76-93$.

MÁRKUS, J., KOVÁCS, G., AND FÉSÜs, L. 1964. The frequency of genes controlling serum $\beta$-globulin types in Hungarian spotted cattle. Acta Vet. (Budapest), 14, 437-442.

matousex, J. 1965. Blood groups of animals. Proc. 9th European Animal Blood Group Conference. Publ. House Czechoslovak Academy of Sciences, Prague.

MILlER, w. J. 1966. Blood groups in Longhorn cattle. Genetics, 54, 391-404.

neimann-sørensen, A. 1958. Blood Groups of Cattle. C.Fr. Mortensen, Copenhagen, 177 pp. RENDEL, J. 1958a. Studies of cattle blood groups. I. Production of cattle isoimmune sera and the inheritance of four antigenic factors. Acta Agr. Scand., 8, 40-61.

RENDEL, J. 1958b. Studies of cattle blood groups. IV. The frequency of the different blood group genes in the Swedish cattle breeds. Acta Agr. Scand., 8, 191-215.

RENDEL, J. 1963. An example of changes in the genetic composition of a cattle breed due to one popular bull. Acta Agr. Scand., 13, 227-238.

ROBERTSON, A. 1965. The interpretation of genotypic ratios in domestic animal populations. Animal Production, 7(3), 319-324.

SANDBERG, K. 1967. Milk protein polymorphism in Swedish cattle with special reference to strain differences within the Swedish Friesian Breed. Acta Agr. Scand., 17, 127-130.

stormont, c. 1952. The F-V and Z systems of bovine blood groups. Genetics, 37, 39-48. TOlle, A. 1960. Die Blutgruppen des Rindes. Verlag Schaper, Hannover, 195 pp.

WAHLUND, s. 1928. Zusammensetzung von Populationen und Korrelationserscheinungen von Standpunkt der Vererbungslehre aus betrachtet. Hereditas, 2, 65-108.

vasenius, L. 1965. Transferrin Polymorphism in Finnish Ayrshire Cattle. Ann. Acad. Scientiarum Fennicae, Series A, IV Biologica 98, 58 pp. 